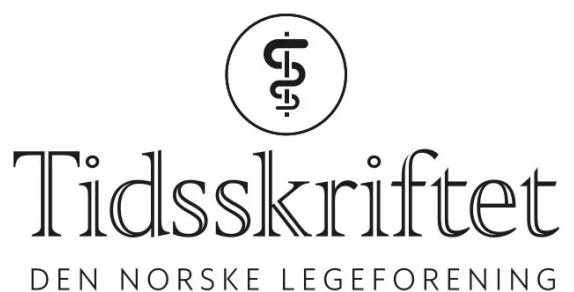

DEN NORSKE LEGEFORENING

\title{
Bruk av hjertesviktpacemaker i Europa
}

NYHETER

\section{ANNE FORUS}

Email:anneforus@hotmail.com

Tidsskriftet

En europeisk multisenterstudie viser at behandling med implantasjon av hjertesviktpacemaker kan være nyttig for flere pasientgrupper enn tidligere antatt. 


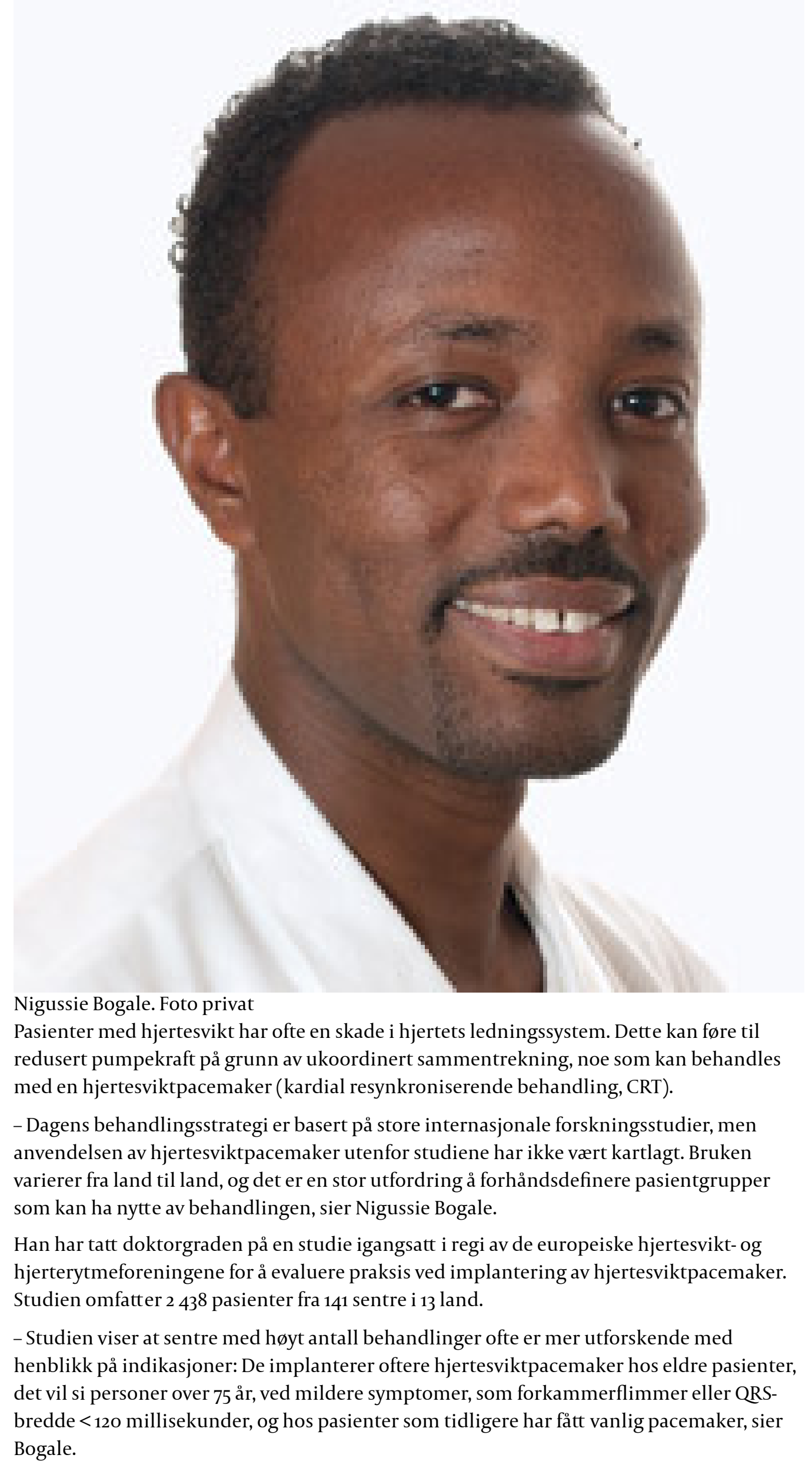


Ett års oppfølgingsdata viste at de fleste pasientene følte seg mye bedre etter implantasjon av hjertesviktpacemaker, og at antall dødsfall og sykehusinnleggelser var sammenliknbare med funn fra tidligere studier. Det var ingen forskjeller i utfall eller grad av komplikasjoner mellom pasienter som ble oppgradert fra vanlig pacemaker til hjertesviktpacemaker og pasienter som fikk implantert hjertesviktpacemaker for første gang.

- Dette er en prospektiv observasjonsstudie av vellykkede hjertesviktpacemakerbehandlinger, så resultatene må tolkes med forsiktighet, sier Bogale.

\section{Disputas}

Nigussie Bogale disputerte for ph.d-graden ved Universitetet i Bergen 20.10. 2011. Tittel på avhandlingen er European Cardiac Resynchronization Therapy (CRT) Survey.

\section{Ordforklaring}

QRS-bredde: Mål for varighet av elektrisk impuls.

Publisert: 24. januar 2012. Tidsskr Nor Legeforen. DOI: 10.4045/tidsskr.11.1421

(C) Tidsskrift for Den norske legeforening 2023. Lastet ned fra tidsskriftet.no 26. april 2023. 